\author{
DOBROSŁAWA ANTONÓW \\ ORCID: 0000-0001-8545-1932 \\ Uniwersytet Wrocławski
}

\title{
Unifikacja opłat stemplowych w okresie rządów sanacji - ustawa z dnia 1 lipca 1926 roku o opłatach stemplowych
}

\section{Wprowadzenie}

Polskie ustawodawstwo dwudziestolecia międzywojennego stanowi podwaliny współczesnych koncepcji normatywnych wielu instytucji prawnych. Uwarunkowania polityczne, społeczne i gospodarcze tego okresu stanowiły istotny kontekst działań legislacyjnych służących odbudowie państwa polskiego. Pierwsze regulacje prawne po odzyskaniu niepodległości przez Polskę niejednokrotnie są pierwowzorami rozwiązań prawnych, które często znajdują swój (bardziej lub mniej odległy pod względem istoty i konstrukcji) odpowiednik w obowiązującym stanie prawnym. Dotyczy to również prawa daninowego, w tym zwłaszcza koncepcji danin nazywanych wówczas opłatami stemplowymi, współcześnie zastąpionych podatkami i opłatami, przede wszystkim opłatą skarbową i podatkiem od czynności cywilnoprawnych ${ }^{1}$. Wiele rozwiązań normatywnych w przedmiocie tych danin czerpie swoją genezę właśnie w rozwiązaniach prawnych dwudziestolecia międzywojennego. Szczególne znaczenie mają przy tym działania prawodawcze przypadające na początek okresu rządów sanacji.

Czas ten, zwłaszcza od wiosny 1926 roku, charakteryzowało polepszenie koniunktury oraz stabilny rozwój gospodarki, który w konsekwencji prowadził do utrwalenia równowagi budżetowej ze wskazaniem na nadwyżkę

1 Na ten temat zob. np. D. Antonów, Opłata skarbowa w polskim porządku prawnym, Warszawa 2017 , s. $101 \mathrm{n}$. 
w roku budżetowym 1926/1927 w wysokości 160,6 mln złotych ${ }^{2}$. Na czas ten przypada również opór wobec koncepcji podwyższania stawek podatkowych i wprowadzania nowych podatków, co jednak, ze względu na rosnące potrzeby publiczne, doprowadziło do wprowadzenia nadzwyczajnego dodatku do danin państwowych ${ }^{3}$. W tym okresie miały też miejsce działania legislacyjne odnośnie do istotnych kwestii społecznych i gospodarczych ${ }^{4}$, w tym w zakresie prawa daninowego ${ }^{5}$. Działania te polegały między innymi na uporządkowaniu regulacji prawnych państw zaborczych w przedmiocie opłat stemplowych, ich unifikacji i uproszczeniu ${ }^{6}$. Efektem tych działań była ustawa $z$ dnia 1 lipca 1926 roku o opłatach stemplowych ${ }^{7}$ (dalej: u.o.s.). Zgodnie z art. 181 u.o.s. weszła ona w życie z dniem 1 stycznia 1927 roku, z wyjątkiem niektórych przepisów, które uzyskały ważność z dniem ogłoszenia, to jest 30 września 1926 roku. Ustawa ta obowiązywała na całym obszarze Rzeczypospolitej, a jej przepisy dotyczące zagranicy miały zastosowanie również do obszaru Wolnego Miasta Gdańska.

W nawiązaniu do ustawodawstwa daninowego tego okresu współczesna literatura formułuje wiele różnych odniesień, ocen ${ }^{8}$ i postulatów ${ }^{9}$ - także na temat u.o.s. Ustawa ta daje początek współczesnej (dwudziestowiecznej) ewolucji kolejnych koncepcji normatywnych kilku danin publicznych, w tym przede wszystkim opłaty skarbowej i podatku od czynności cywilnoprawnych. Badania nad tymi daninami, zwłaszcza pogłębione badania nad opłatą skarbową, dowodzą konieczności jej

2 A. Albert, Najnowsza historia Polski 1914-1993, Warszawa 1995, s. 222, 229-232.

3 L. Adam, Podatki i opłaty w kapitalizmie, Warszawa 1962, s. 141-142; I. Weinfeld, Daniny. Podatki, opłaty, cła i akcyzy. Skarbowości polskiej tom II - wydanie piate, Warszawa 1937, s. 130.

${ }^{4} \mathrm{~W}$ tym okresie uchwalone zostały tak istotne regulacje (w tym regulacje o charakterze kompleksowym i systemowym), jak ustawa karna skarbowa z dnia 2 sierpnia 1926 roku (Dz.U. $\mathrm{Nr}$ 105, poz.609), ustawa $\mathrm{z}$ dnia 2 sierpnia 1926 roku o zwalczaniu nieuczciwej konkurencji (Dz.U. Nr 96, poz. 559), ustawa z dnia 2 sierpnia 1926 roku o prawie właściwym dla stosunków prywatnych wewnętrznych (określana również jako Prawo prywatne międzydzielnicowe; Dz.U. Nr 101, poz. 580), ustawa $\mathrm{z}$ dnia 2 sierpnia 1926 roku o prawie właściwym dla stosunków prywatnych międzynarodowych (inaczej: Prawo prywatne międzynarodowe; Dz.U. Nr 101, poz. 581), ustawa z dnia 1 lipca 1926 roku o stosunkach służbowych nauczycieli (Dz.U. Nr 92, poz. 530).

5 Tak np. ustawa z dnia 2 sierpnia 1926 roku o podatku od lokali (Dz.U. Nr 94, poz. 550), ustawa z dnia 1 marca 1927 roku o samoistnym podatku wyrównawczym dla gmin wiejskich byłego zaboru rosyjskiego (Dz.U. Nr 27, poz. 208).

${ }^{6} \mathrm{Na}$ ten temat zob. I. Weinfeld, Skarbowość polska, Warszawa 1933, s. $17 \mathrm{n}$.

7 Tekst pierwotny: Dz.U. poz. 570. W artykule uwzględniana jest pierwotna wersja ustawy, obowiązująca w dniu jej ogłoszenia.

8 Zob. np. L. Adam, op. cit., s. 99-144.

9 Na przykład Irena Czaja-Hliniak w odniesieniu do problematyki opłat i dopłat publicznych zwraca uwagę, że ,w wielu kwestiach regulacje międzywojenne godne są uwagi przy projektowaniu i stosowaniu aktualnych rozwiązań" - eadem, Wybrane zagadnienia opłat publicznych w międzywojennych finansach komunalnych, [w:] Regnare, gubernare, administrare. $Z$ dziejów administracji, sądownictwa i nauki prawa, red. S. Grodziski, A. Dziadzio, Kraków 2012, s. 277. 
oceny w kontekście analizy historycznej, której po odbudowie państwa polskiego początek daje właśnie u.o.s. ${ }^{10}$

Niniejszy artykuł ma na celu omówienie cech i konstrukcji u.o.s. oraz jej miejsca w polskim prawodawstwie okresu rządów sanacji. Wnioski wynikające z tej analizy mogą posłużyć ocenie współczesnych rozwiązań normatywnych w przedmiocie niektórych danin, w tym opłaty skarbowej i podatku od czynności cywilnoprawnych.

\section{Cel i miejsce u.o.s. w prawodawstwie sanacyjnym}

Ustawa o opłatach stemplowych z 1926 roku określana jest mianem ,podstawowej dla okresu międzywojnia w zakresie państwowych opłat publicznych"11 oraz „kompleksowej regulacji państwowych opłat publicznych”12. Jest także charakteryzowana jako ustawa, która zunifikowała opłaty stemplowe ${ }^{13}$. Podstawowa, kompleksowa, unifikująca — te cechy u.o.s. definiują jej miejsce i cel w prawodawstwie polskim w analizowanym okresie. Spośród tych trzech cech unifikacja wydaje się mieć podstawowe znaczenie. Dlatego też została wskazana w tytule niniejszego artykułu. Potrzeba unifikacji miała kluczową wagę i to ona definiowała zasadniczy cel omawianej ustawy. Ustawa ta zastąpiła bowiem liczne regulacje państw zaborczych, dotyczące różnych danin uznawanych (głównie ze względu na formę płatności) za opłaty stemplowe ${ }^{14}$. W literaturze tego okresu pisano, że

Unifikacja przepisów w dziedzinie opłat stemplowych nastąpiła z dniem 1 stycznia $1927 \mathrm{r}$. Do tego czasu obowiązywało przedwojenne ustawodawstwo dzielnicowe, fragmentarycznie uzupełniane przez władze okupacyjne w czasie wojny, a następnie przez ustawy polskie. W rezultacie utworzyło się w Polsce 9 obszarów, na których obowiązywały rozmaite, bardzo zawiłe, ogółowi płatników mało znane, przepisy. Przepisy te ujednostajniła ustawa z 1.7.1926, uchylająca równocześnie dawniejsze przepisy o opłatach z wyjątkiem kilku wyraźnie utrzymanych ${ }^{15}$.

$10 \mathrm{Na}$ temat analizy historycznej opłaty skarbowej z uwzględnieniem znaczenia u.o.s. jako pierwszej polskiej ustawy o opłatach stemplowych po odzyskaniu niepodległości zob. D. Antonów, op. cit., s. 72-79. Na temat wykorzystania koncepcji zawartych w u.o.s. we współczesnych regulacjach prawnych zob. ibidem, passim.

11 I. Czaja-Hliniak, Opłaty i dopłaty w Polsce międzywojennej, Kraków 2013, s. 76.

12 Ibidem, s. 111.

13 Pojęciem unifikacji w odniesieniu do kompleksowej regulacji w przedmiocie opłat stemplowych w ustawie z 1926 roku posłużył się na przykład I. Weinfeld, Daniny..., s. 130.

14 Pełny wykaz aktów prawnych państw zaborczych, które zostały zastąpione przez u.o.s. został wskazany w D. Antonów, op. cit., s. 72-73.

15 I. Weinfeld, Daniny..., s. 130. 
Te szczególne uwarunkowania historyczne i polityczne Polski po odzyskaniu niepodległości determinowały w pierwszej kolejności cele działań prawodawczych. Normatywnym wyrazem unifikacji regulacji prawnych państw zaborczych w ramach u.o.s. są obszerne przepisy zawarte w części III u.o.s. — Przepisy końcowe. W normach tych ustawodawca odniósł się do przepisów dotychczasowych oraz określił czasowy, merytoryczny i terytorialny zakres zastosowania u.o.s. do stosunków i czynności prawnych powstałych pod rządami przepisów państw zaborczych.

Zastąpienie jednym aktem prawnym (u.o.s.) wielu regulacji mających swoje źródło w kulturze prawnej państw obcych wymagało nie tylko zabiegu legislacyjnego polegającego na zastąpieniu jedną ustawą kilkudziesięciu aktu prawnych o różnym charakterze (nazwie, konstrukcji, randze, przynależności do różnych systemów i kultur prawnych), lecz co ważne także opracowania jednolitej koncepcji normatywnej grupy danin nazwanych opłatami stemplowymi w miejsce licznych zróżnicowanych koncepcji w tym zakresie, wynikających z prawodawstwa dotychczas obowiązującego na ziemiach polskich. Ten akt prawny należy więc postrzegać w kategoriach pierwotnej polskiej wizji opłat stemplowych. Wizja ta czerpie jednak w sposób naturalny z ustawodawstw państw obcych. Ustawa z 1926 roku jest zatem aktem prawnym, w którym widoczne pozostają wpływy ustawodawstwa państw zaborczych.

Uregulowanie zbioru danin nazwanych opłatami stemplowymi w jednym akcie prawnym nadaje u.o.s. również walor ustawy podstawowej dla tej grupy świadczeń. Pod tym względem była to dotychczas najbardziej obszerna regulacja w przedmiocie opłat stemplowych (skarbowych) w polskim porządku prawnym. Obejmowała swoim zakresem przedmiotowym różne świadczenia pieniężne, niekiedy o dalece zróżnicowanej naturze normatywnej. Niemniej jednak, ówczesny prawodawca dostrzegł wspólny mianownik tych świadczeń, a mianowicie szeroko pojęty związek z obrotem gospodarczym udokumentowanym na piśmie (w formie dokumentów). Jej charakter podstawowy niewątpliwie wynika również z istoty czynności podlegających tym opłatom. Były to czynności powszechne w codziennym życiu i związane z legalnym funkcjonowaniem $\mathrm{w}$ gospodarce i społeczeństwie, czyli tak zwane czynności ,życia codziennego", o czym dalej.

Ustawa ta spełniała także kryterium kompleksowości. Był to obszerny akt prawny, składający się z 181 artykułów. Przedmiotem jego regulacji były zarówno kwestie ogólne - uniwersalne dla wszystkich danin zaliczanych do opłat stemplowych, jak i szczegółowe, odnoszące się do każdej z nich z osobna. Były tam nie tylko przepisy materialnoprawne (kreujące konstrukcję: podmiot, przedmiot i wysokość opłat stemplowych, na przykład część I, rozdział 3 u.o.s., dotyczący osób obowiązanych do uiszczenia opłaty), lecz także przepisy proceduralne (odnoszące się na przykład do sposobu obliczenia opłaty — część I, rozdział 2 u.o.s., czy część I, rozdział 4 dotyczący uiszczenia opłaty). W ustawie tej znalazły się 
również regulacje co do sankcji i zasad odpowiedzialności za naruszenie przepisów o opłatach skarbowych (część I, rozdział 7 - Naruszenie przepisów o opłatach skarbowych). Jeden akt prawny zawierał zatem kompleks regulacji niezbędnych do prawidłowego poboru danin publicznych zaliczanych do opłat stemplowych.

Całokształt działań legislacyjnych zmierzających do unifikacji regulacji w przedmiocie opłat stemplowych stał się też okolicznością sprzyjającą rewizji - uporządkowaniu i uproszczeniu dotychczas zróżnicowanego i rozproszonego prawodawstwa w przedmiocie wielu danin ${ }^{16}$. Na etapie prac legislacyjnych rozważane były bowiem rozwiązania służące uproszczeniu i zapewnieniu transparentności regulacji prawnych, w tym na przykład w kwestii technicznego układu taryfy tych opłat ${ }^{17}$. Wydaje się, że wiele rozwiązań służących temu celowi rzeczywiście znalazło się w u.o.s. Ponadto dbałości ówczesnego prawodawcy o uproszczenie i poprawę jakości procesu stosowania prawa dowodzą również liczne inne działania, takie jak chociażby obszerne akty wykonawcze oraz tak zwane wykładnie, o których mowa dalej.

Wszystkie wymienione cechy u.o.s. przesądzają o jej istotnym miejscu w prawodawstwie analizowanego okresu historycznego. Bez wątpienia ten akt prawny można określić jako podstawowy w przedmiocie rozlicznych danin nazywanych ówcześnie opłatami stemplowymi ${ }^{18}$. Co więcej, ustawa ta ukształtowała na długi czas koncepcję normatywną opłat stemplowych w ogólności, a także koncepcje szczegółowe poszczególnych danin zaliczanych do tej ogólnej kategorii. Ustawa ta obowiązywała bowiem przez ponad dwadzieścia lat. Stanowiła więc najdłużej obowiązujący akt prawny regulujący konstrukcję opłat stemplowych (później nazywanych skarbowymi) w polskim porządku prawnym.

Ustawę o opłatach stemplowych z 1926 roku zastąpił dekret z dnia 3 lutego 1947 roku o opłacie skarbowej ${ }^{19}$. Pomimo że z dniem jego wejścia $\mathrm{w}$ życie zakończył się okres obowiązywania u.o.s., wiele rozwiązań przyjętych w tej ustawie zostało powielonych w kolejnych aktach prawnych, a nawet jest zauważalnych $\mathrm{w}$ obowiązującym stanie prawnym. Ustawę tę niewątpliwie należy ocenić również jako regulację obszerną i kompleksową, która była wyrazem próby uporządkowania i uregulowania $\mathrm{w}$ jednym akcie prawnym różnych świadczeń. Nie bez znaczenia jest też jej zakres, a mianowicie jej kompleksowość i niemalże wyczerpujący charakter. W związku z tym można zaryzykować ocenę u.o.s. w kategoriach aktu prawnego o charakterze systemowym dla dużej kategorii instytucji prawnofinansowych.

${ }^{16} \mathrm{Na}$ temat rewizji stanu prawodawstwa w zakresie opłat stemplowych w kontekście prac ustawodawczych nad u.o.s. zob. D. Antonów, op. cit., s. 74-75.

$17 \mathrm{Na}$ ten temat zob. ibidem, s. 76-77 i powołana tam literatura.

$18 \mathrm{Na}$ temat kategorii opłat stemplowych w literaturze okresu dwudziestolecia międzywojennego zob. I. Czaja-Hliniak, Opłaty..., s. 34-57.

19 Tekst pierwotny: Dz.U. poz. 107. 


\section{Tytuł u.o.s.}

Analizowana ustawa nosiła tytuł „o opłatach stemplowych”. Tytuł ten wymaga skomentowania, ponieważ z jednej strony nawiązywał on do pewnych tradycji prawodawczych, z drugiej zaś kreował pewien stan prawodawstwa w przedmiocie opłat na przyszłość, a jego konsekwencji można upatrywać również współcześnie ${ }^{20}$.

Tytuł u.o.s. w pierwszej kolejności wskazuje na zbiór opłat (liczba mnoga „opłaty”). Oznacza to, że przedmiotem regulacji tej ustawy nie była jedna danina, ale ich pewna grupa lub kategoria, na którą składały się publiczne świadczenia pieniężne o zróżnicowanej naturze prawnej, odpowiadające zarówno opłatom, jak i podatkom. $Z$ tego powodu należy podkreślić, że tytuł tej ustawy nie był adekwatny do wszystkich świadczeń w niej uregulowanych. W literaturze z zakresu prawa daninowego w kontekście tej ustawy wskazuje się bowiem, że w aktach prawnych okresu międzywojennego widoczna jest rozbieżność terminologii i przedmiotu regulacji ${ }^{21}$. Stan ten, wprowadzony u.o.s., utrwalił na długi czas w polskim prawodawstwie tendencje w zakresie rozbieżności między nazwą świadczeń i tytułem aktu prawnego a naturą (charakterem prawnym) poszczególnych świadczeń. Dotyczy to przede wszystkim opłat publicznych (kwestia nazywania podatków opłatami).

Tytuł u.o.s. wskazuje również na element łączący wszystkie uregulowane tam daniny. Ich wspólnym mianownikiem jest związek ze stemplem. Należy zauważyć, że u.o.s. była ostatnim polskim aktem prawnym, który w swoim tytule zawierał takie właśnie odniesienie do stempla ${ }^{22}$. W tym zakresie ustawodawca nawiązał do tradycji i uwarunkowań historycznych sposobów dokumentacji obrotu gospodarczego. W uzasadnieniach brzmienia tytułu tej ustawy powoływano się bowiem na tradycyjną nazwę przyjętą dla pewnej grupy danin — nazwa ta nie miała waloru naukowego (nauka prawa daninowego nie wyróżniała takiej jednorodnej kategorii danin jak opłaty stemplowe), niemniej jednak nawiązywała do tradycji i przyzwyczajeń podatników ${ }^{23}$. W piśmiennictwie wskazywano, że nazwa opłat stemplowych wiąże się z tym, że dawniej uiszczano te opłaty przy użyciu papieru lub znaczka stemplowego ${ }^{24}$. Ówczesny ustawodawca zdecydował się zatem na zachowanie nazwy historycznej nie tylko ze względu na potrzebę wypracowania kryterium pozwalającego na połączenie regulacji $\mathrm{w}$ przedmiocie

20 Na ten temat D. Antonów, op. cit., s. 104-105.

21 I. Czaja-Hliniak, Opłaty..., s. 75.

22 D. Antonów, op. cit., s. 105.

${ }^{23} \mathrm{Na}$ kwestie te zwracał uwage jeszcze na etapie wstępnych projektów ustawodawczych A. Rosenkranz, O istocie opłaty stemplowej, referat wygłoszony na posiedzeniu sekcji ekonomicznej Towarzystwa Prawniczego, cz. I, „Gazeta Sądowa Warszawska” 1924, nr 18, s. 226. Szerzej na ten temat zob. D. Antonów, op. cit., s. 74-75.

${ }^{24}$ I. Weinfeld, Daniny..., s. 131. 
różnych danin w jednym akcie prawnym, lecz także z powodu obecności tej nazwy w świadomości podatników. Takie podejście z pewnością sprzyjało popularyzacji obowiązku ponoszenia tej kategorii świadczeń, a w perspektywie mogło ułatwiać ich pobór.

Odnieść należy się również do słowa „opłata” zawartego w tytule u.o.s. W piśmiennictwie okresu obowiązywania u.o.s. formułowano bowiem obawy co do zakresu znaczenia tego słowa. Źródłem wątpliwości była jego wieloznaczność w ówczesnym polskim języku prawnym. Podkreślano z pełną świadomością, że słowu temu odpowiadają $\mathrm{w}$ polskim ustawodawstwie również inne pojęcia inne kategorie świadczeń. Zauważano, że polski ustawodawca powielił w tym zakresie nomenklaturę rosyjską ${ }^{25}$ (co stanowi tylko jeden z przykładów wpływów prawodawstwa państw zaborczych, o czym była mowa wcześniej). Ustawa o opłatach stemplowych z 1926 roku utrwaliła więc w polskim porządku prawnym, nadal zresztą aktualne ${ }^{26}$, wątpliwości związane z pojęciem opłaty. Analiza obowiązującego porządku prawnego wskazuje bowiem, że termin ten jest stosowany w odniesieniu do świadczeń o zróżnicowanym charakterze prawnym. Tak również, już w odniesieniu do u.o.s., w ówczesnym piśmiennictwie komentowano złożoną naturę świadczeń pieniężnych nazywanych opłatami. Podkreślano, że od opłat stemplowych trzeba odróżnić na przykład opłaty komorników, które

nie są opłatami w znaczeniu skarbowym, gdyż nie wpływają do Skarbu Państwa, mimo że unormowane są przez Państwo i mimo że uprawnieniu do poboru są osobami szczególnego u Państwa zaufania. Są one tylko należnościami, do których te osoby mają prawo według ustalonej przez Państwo taryfy ${ }^{27}$.

Analizowana ustawa utrwaliła zatem w polskiej kulturze prawnej zróżnicowane zastosowanie pojęcia opłaty na potrzeby rozmaitych świadczeń pieniężnych. $Z$ racji dość uniwersalnego rozumienia tego pojęcia w języku powszechnym trudno jest z tym walczyć. Niemniej jednak warto podkreślić, że u.o.s. daje normatywny początek utrwalonej już tendencji posługiwania się pojęciem opłaty w odniesieniu do różnych świadczeń pieniężnych na gruncie polskiego języka prawnego nie tylko w odniesieniu do opłat publicznych.

\section{Konstrukcja i przedmiot regulacji u.o.s.}

Ustawa o opłacie stemplowej składała się z trzech części: Postanowienia ogólne, Postanowienia szczegółowe oraz Przepisy końcowe.

25 Ibidem.

$26 \mathrm{Na}$ temat pojęcia opłaty w polskim języku prawnym D. Antonów, Pojęcie opłaty w polskim języku prawnym, [w:] Księga jubileuszowa ku czci profesor Krystyny Sawickiej. Gromadzenie i wydatkowanie środków publicznych. Zagadnienia finansowoprawne, red. W. Miemiec, Wrocław 2017, s. $483-498$.

27 I. Weinfeld, Daniny..., s. 131. 
Część I - Postanowienia ogólne zawierała zasadnicze regulacje o charakterze uniwersalnym, dotyczące opłat stemplowych w ogólności. Kluczowe znaczenie miał art. 1 u.o.s., zgodnie z którym opłatom stemplowym podlegały pisma oraz czynności prawne. W tym samym przepisie ustawodawca zdefiniował pismo na potrzeby tej ustawy. Przyjęto, że ilekroć w ustawie jest mowa o piśmie stwierdzającym umowę, należy przez to rozumieć nie tylko pismo podpisane przez obie strony, lecz także podpisane przez jedną stronę, jeżeli zostało bądź wręczone stronie drugiej, bądź przedstawione sądowi w celu dokonania wpisu w księdze wieczystej, bądź sporządzone albo uwierzytelnione sądownie lub notarialnie. Artykuł 1 u.o.s. kreował w najszerszym zakresie przedmiot opłat stemplowych i jednocześnie ujawniał ich zróżnicowany charakter prawny. Opłaty te były pobierane zarówno od pism (dokumentów), jak i od czynności prawnych. Najistotniejszym walorem tego przepisu było powiązanie obowiązku z tytułu opłat stemplowych $\mathrm{z}$ istnieniem pisma (dokumentu). Przepis ten komentowano w taki sposób, że akt obrotu podlegał opłacie tylko wówczas, gdy ujawnił się w piśmie (dokumencie) stwierdzającym czynność prawną dwustronną lub jednostronną. Opłata należna była tylko od pism tworzących prawa i obowiązki ${ }^{28}$.

Uszczegółowienie przedmiotu opłat stemplowych wynika z treści części II u.o.s. - Postanowienia szczegółowe. Opłatom stemplowym podlegały (uregulowane w kolejnych rozdziałach tej części): pisma dotyczące przejścia własności nieruchomości (rozdział 10), pisma dotyczące praw do ciał kopalnych (rozdział 11), pisma stwierdzające sprzedaż i zamianę rzeczy ruchomych oraz przelew (cesję) praw (rozdział 12), obrót papierów wartościowych (rozdział 13), pisma dotyczące praw rzeczowych na rzeczy cudzej (rozdział 14), pisma stwierdzające dzierżawę i najem rzeczy (rozdział 15), pisma stwierdzające umowę o świadczenie usług (rozdział 16), pisma stwierdzające umowę składu (rozdział 17), pisma związane z ubezpieczeniami i umowy o rentę dożywotnią (rozdział 18), pisma dotyczące umowy spółki i innych zrzeszeń (rozdział 19), pełnomocnictwa (rozdział 20), obligi (rozdział 21), weksle (rozdział 22), przekazy, czeki i zlecenia wypłaty (rozdział 23), pisma dotyczące umów majątkowych małżeńskich (rozdział 24), pisma stwierdzające dział majątku wspólnego (rozdział 25), pisma stwierdzające ugodę (układ pojednawczy) (rozdział 26), pisma stwierdzające umowy przygotowawcze oraz punktacje (to jest zgodnie z art. 135 u.o.s. pisma tymczasowo stwierdzające istotne punkty umowy, a wiążące kontrahentów, takie jak umowa ostateczna) (rozdział 27), pokwitowania (rozdział 28), pisma niewymienione we wskazanych rozdziałach (rozdział 29), podania (rozdział 30) oraz świadectwa (rozdział 31).

Obszerny katalog kategorii przedmiotu opłat stemplowych wskazuje, że opłaty te pobierane były w związku z pisemną dokumentacją większości (jeśli nie wszystkich) działań legalnych wszelkich podmiotów życia społecznego (osób fizycznych, spółek). Pisma te odnosiły się do różnych sfer życia. W przeważającej

28 Ibidem. 
większości były to pisma dotyczące relacji prywatnych związanych z obrotem majątkowym (umów, pokwitowań, pełnomocnictw, ubezpieczeń, weksli). Były to jednak również (choć w mniejszym zakresie) pisma dokumentujące sytuację jednostki w relacji z władzą państwową, a więc pisma stanowiące emanację władzy państwowej (na przykład świadectwa - w rozumieniu u.o.s. były to różne dokumenty i zaświadczenia wydawane przez urzędy państwowe, sądy i notariuszy) oraz podania wnoszone do urzędów państwowych. Zakres przedmiotu opłat stemplowych był określany jako „liczne i różnorodne objawy życia gospodarczego i prawnego" 29, które bardzo często wiążą się z wykonywaniem zajęć zawodowych, przez co opłaty stemplowe dla wielu stanowią „chleb powszedni”"

Całokształt przedmiotu ustawy dowodzi, że opłaty stemplowe na gruncie u.o.s. odpowiadały współczesnym opłatom administracyjnym, opodatkowaniu obrotu cywilnoprawnego, a nawet zawierały elementy tożsame z opodatkowaniem nieodpłatnych transferów majątkowych (współcześnie opodatkowanych podatkiem od spadków i darowizn). Ówczesna literatura komentowała zakres przedmiotowy u.o.s. w następujący sposób:

W istocie swej są opłaty stemplowe przeważnie daninami od wyliczonych w ustawie aktów obrotu majątkowego. Nadto jednak normuje ta ustawa opłaty od podań i opłaty od świadectw, które nie nawiązują do obrotów majątkowych, lecz do spowodowanych przez płatnika usług i świadczeń władzy ${ }^{31}$.

Należy podkreślić, że obciążenie obrotu majątkowego stanowiło podstawowy, dominujący element zakresu przedmiotowego u.o.s. Odpłatność związana z działalnością władzy była oceniana jako uzupełniająca. Niemniej jednak analiza historyczna u.o.s. jest zasadna zarówno w kontekście współczesnej opłaty skarbowej i innych opłat administracyjnych, jak i podatku od czynności cywilnoprawnych i podatku od spadków i darowizn. Trzeba ponadto zauważyć, że koncepcja stawki niektórych opłat stemplowych wskazywała, że opłaty te w pewnym sensie nawiązywały również do opodatkowania przychodów. Przykładowo zgodnie $z$ art. 90 u.o.s. pisma stwierdzające umowę o świadczenie usług podlegały opłacie stemplowej w wysokości 0,2\% wynagrodzenia za te usługi. Spektrum możliwych odniesień u.o.s. względem obowiązującego porządku prawnego poszerza się zatem także o podatki dochodowe i przychodowe. Zauważyć wreszcie należy, że niektóre spośród przedmiotów opłat stemplowych na gruncie u.o.s. są obecnie wolne od danin publicznych ${ }^{32}$. Zakres obciążeń publicznych z tytułu opłat stemplowych, w odniesieniu do współczesności, można więc ocenić jako stosunkowo restrykcyjny.

29 A. Rosenkranz, Taryfy opłat stemplowych w uktadzie alfabetycznym z dołaczeniem dostownego tekstu ustawy o oplatach stemplowych z dn. 1 lipca 1926 r., Warszawa 1927, s. III.

30 Ibidem.

31 I. Weinfeld, Daniny..., s. 131.

$32 \mathrm{Na}$ temat rezygnacji z poboru opłaty skarbowej od weksli zob. np. Z. Ofiarski, Ustawy o opłacie skarbowej, o podatku od czynności cywilnoprawnych. Komentarz, Warszawa 2009, s. 38. 
Odpowiednio w rozbudowanych przepisach szczegółowych części II u.o.s. określone zostały adekwatnie do każdej z kategorii przedmiotu opłaty, podmioty zobowiązane do jej uiszczenia, wysokość opłaty (ustalana jako kwota lub procent pewnej wartości) oraz katalogi pism wolnych od opłat (zwolnienia przedmiotowe) i podmiotów zwolnionych z obowiązku ponoszenia opłat (uwolnienia osobiste).

Kwestie proceduralne związane $\mathrm{z}$ obliczeniem i zapłatą opłat stemplowych regulowały przepisy ogólne z części I u.o.s., to jest rozdział 2 dotyczący sposobu obliczenia opłaty, rozdział 4 o uiszczeniu opłaty, rozdział 5 traktujący o przedawnieniu prawa do żądania opłaty, rozdział 6 o nadzorze nad prawidłowością uiszczenia opłat, rozdział 8 dotyczący środków odwoławczych w wypadkach nienależnie uiszczonej opłaty oraz rozdział 9 traktujący o zasadach doręczania nakazów płatniczych i innych decyzji. Zakres regulacji proceduralnych u.o.s. był więc niezwykle szeroki. Ustawodawca w sposób wszechstronny uregulował niemalże wszelkie kwestie związane z procedurą zapłaty opłat stemplowych, ale i konsekwencji nierealizowania tego obowiązku. Spośród tych przepisów warto zwrócić uwagę przede wszystkim na sposób zapłaty opłat stemplowych. Zgodnie z art. 17 u.o.s. opłata stemplowa uiszczana była (w zależności od przedmiotu opłaty) bądź przez użycie papieru stemplowego lub znaczków stemplowych, bądź przez wpłacenie gotówki do kasy skarbowej lub do rąk innego organu uprawnionego do poboru (specjalnego poborcy). Forma zapłaty — papier stemplowy lub znaczki stemplowe - choć nieobowiązująca w wypadku każdej kategorii przedmiotu opłat stemplowych, miała stanowić kryterium łączące wszystkie świadczenia publiczne uregulowane w omawianej ustawie.

\section{Wykładnie u.o.s.}

Ustawa o opłatach stemplowych odgrywała bardzo istotną rolę jako akt prawny obciążający powszechny obrót majątkowy oraz działalność władzy na rzecz obywateli. Był to obszerny i kompleksowy akt prawny. Już na etapie działań legislacyjnych ówczesny prawodawca dał wyraz dążenia do wyczerpującego uregulowania wielu, jeśli nie wszelkich kwestii związanych z ponoszeniem opłat stemplowych. Ponadto kwestie szczegółowe uregulowane zostały w licznych rozporządzeniach wykonawczych do u.o.s. Na szczególną uwagę zasługuje zwłaszcza rozporządzenie Ministra Skarbu z dnia 20 listopada 1926 roku wydane: co do $\S \S 54-64,68-73,78-89,96$ i 97 w porozumieniu z Ministrem Sprawiedliwości; co do $\S 102 \mathrm{w}$ porozumieniu z Ministrem Spraw Wewnętrznych; co do $\S \S 107$ i $175 \mathrm{w}$ porozumieniu z Ministrem Przemysłu i Handlu; co do $\S 122 \mathrm{w}$ porozumieniu z Ministrem Pracy i Opieki Społecznej; co do $\S \S 123,124,167$ i 168 w porozumieniu z Ministrem Komunikacji; co do §§ 99-101 oraz 103-106 w porozumieniu z Ministrem Reform Rolnych; co do $\S$ 163, 171 i 178 w porozumieniu z Ministrem Spraw Zagranicznych — a zawierające przepisy wykonawcze 
do ustawy z dnia 1 lipca 1926 roku o opłatach stemplowych ${ }^{33}$ (dalej: rozporządzenie). Był to akt prawny o specyficznym charakterze. Uszczegóławiał bowiem u.o.s., zawierał regulacje o charakterze wykonawczym, a miejscami jego treść można w zasadzie ocenić w kategoriach swoistego komentarza - wyjaśnień do poszczególnych artykułów u.o.s. Przepisy te, zgodnie z $§ 201$ rozporządzenia, weszły w życie równocześnie z u.o.s., to jest z dniem 1 stycznia 1927 roku. Nieodzowne zatem dla stosowania u.o.s. było równoczesne korzystanie z norm tego rozporządzenia.

Niemniej jednak niezależnie od obszernych wyczerpujących regulacji u.o.s. oraz rozporządzeń wykonawczych gromadzenie opłat stemplowych nastręczało trudności interpretacyjnych. W celu zapewnienia ułatwień w procesie stosowania u.o.s. wypracowana została praktyka publikacji urzędowych wykładni tej ustawy. Wykładnia u.o.s. była ogłaszana w Dzienniku Urzędowym Ministerstwa Skar$\mathrm{bu}^{34}$. Publikowanych wykładni było bardzo dużo. Istotne było zatem ustalenie ich charakteru prawnego. Obowiązywały one władze skarbowe, nie zaś podmioty, na których ciążyły opłaty stemplowe. Jak podkreślano w literaturze,

wobec jednak małych stosunkowo kwot, o jakie najczęściej chodzi, a długiego i kosztownego przewodu przed Najwyższym Trybunałem Administracyjnym ma ona [wykładnia - D.A.] decydujące znaczenie dla bardzo znacznej większości spraw ${ }^{35}$.

Oznacza to, że analiza u.o.s. w kontekście unifikacji opłat stemplowych nie powinna ograniczać się wyłącznie do oceny rozwiązań normatywnych. Nie mniej ważne są również podjęte przez państwo działania służące ułatwieniu praktyki stosowania u.o.s. i eliminowaniu zbędnych i kosztownych sporów w przedmiocie tych opłat. Wykładnie u.o.s. mające walor swoistych interpretacji urzędowych dopełniały całokształtu rozwiązań systemowych w przedmiocie tak znacznej grupy danin publicznych.

\section{Podsumowanie}

Ustawa o opłatach stemplowych z 1926 roku stanowiła obszerny, kompleksowy akt prawny z zakresu prawa daninowego. W okresie dwudziestolecia międzywojennego była to bez wątpienia regulacja prawna o istotnym znaczeniu, dotyczyła bowiem dużej grupy danin publicznych. Jej konstrukcja, treść oraz praktyka stosowania (publikowane wykładnie) wpisują się w tendencje polityczne i prawne czasu jej obowiązywania. Stanowi ona wyraz dążenia do odbudowy polskiej skarbowości oraz uporządkowania polskiego prawodawstwa w zakresie znacznej grupy danin publicznych nazwanych zbiorczo opłatami stemplowymi.

33 Dz.U. Nr 123, poz. 713.

34 Szerzej na ten temat zob. D. Antonów, Optata..., s. 75.

35 I. Weinfeld, Daniny..., s. 131. 
Była nie tylko aktem prawnym zastępującym zbiór kilkudziesięciu innych aktów obwiązujących na ziemiach polskich przed odzyskaniem niepodległości. Wprowadzała bowiem również kompleksową koncepcję normatywną dla całej grupy danin związanych z szeroko pojętym obrotem gospodarczym (w przeważającej większości) oraz (dodatkowo) z działalnością władzy państwowej. Była to więc regulacja o charakterze systemowym. Jakość i zakres regulacji tej ustawy, a zwłaszcza jej publikowane wykładnie, dowodzą dążenia władz tego okresu do ukształtowania transparentnej praktyki stosowania prawa daninowego i gromadzenia danin publicznych. Na docenienie zasługuje kompleksowość tej regulacji, wyodrębnienie części ogólnej i szczegółowej, regulacje materialnoprawne oraz proceduralne (bardzo szczegółowe), a także koncepcja sankcji za nieprzestrzeganie przepisów tej ustawy. Bez wątpienia u.o.s. stanowiła więc akt unifikacji znacznej grupy danin publicznych o istotnym znaczeniu dla obrotu gospodarczego i działalności administracji państwowej tego okresu. Niezależnie od możliwości formułowania ocen krytycznych względem niektórych rozwiązań przyjętych w tej ustawie niewątpliwie uznać ją można za sukces odbudowywanej skarbowości polskiej. Jej ocena powinna bowiem uwzględniać kontekst historyczny jej uchwalenia i obowiązywania. Wszelkie wątpliwości związane z łączeniem w jednym akcie prawnym i pod jedną nazwą świadczeń odpowiadających różnym podatkom i opłatom ustępują walorom wynikającym z działań unifikacyjnych i rewizyjnych w zakresie dotychczas obowiązujących przepisów prawa państw zaborczych.

Ocena u.o.s. nie może ograniczać się jedynie do jej miejsca w systemie prawnym okresu jej obowiązywania. Równie istotne są wpływy jej treści na ewolucję prawa daninowego w Polsce, w tym zwłaszcza w zakresie opodatkowania obrotu prywatnoprawnego (czynności cywilnoprawnych) oraz opłat administracyjnych (szczególnie opłaty skarbowej). Ustawa ta wprowadziła i na długi czas utrwaliła w polskim porządku prawnym tendencję do łączenia regulacji w przedmiocie danin publicznych o różnym charakterze prawnym (podatki i opłaty). Dokument ten stanowi także wyraz tendencji legislacyjnej przejawiającej się rozbieżnością pomiędzy nazewnictwem i charakterem prawnym danin publicznych. Pomimo negatywnej oceny wskazanych tendencji należy jednak podkreślić, że niektóre zasługujące na aprobatę rozwiązania przyjęte $\mathrm{w}$ tej ustawie przetrwały w różnej formie w polskim ustawodawstwie do dziś. Bez wątpienia zatem ustawa ta odegrała istotną rolę w ewolucji historycznej polskich danin publicznych.

Reasumując, należy docenić przede wszystkim walory unifikacyjne u.o.s. Uwzględniając realia polityczne i gospodarcze w chwili jej uchwalenia, wszelkie wątpliwości oraz krytyka przyjętych rozwiązań ustępują walorom wynikającym $\mathrm{z}$ dążenia do porządkowania systemu danin publicznych odradzającej się skarbowości polskiej. 


\section{Bibliografia}

\section{Literatura}

Adam L., Podatki i opłaty w kapitalizmie, Warszawa 1962.

Albert A., Najnowsza historia Polski 1914-1993, Warszawa 1995.

Antonów D., Oplata skarbowa w polskim porzadku prawnym, Warszawa 2017.

Antonów D., Pojęcie opłaty w polskim języku prawnym, [w:] Księga jubileuszowa ku czci profesor Krystyny Sawickiej. Gromadzenie i wydatkowanie środków publicznych. Zagadnienia finansowoprawne, red. W. Miemiec, Wrocław 2017.

Czaja-Hliniak I., Opłaty i dopłaty w Polsce międzywojennej, Kraków 2013.

Czaja-Hliniak I., Wybrane zagadnienia opłat publicznych $w$ międzywojennych finansach komunalnych, [w:] Regnare, gubernare, administrare. $Z$ dziejów administracji, sądownictwa i nauki prawa, red. S. Grodziski, A. Dziadzio, Kraków 2012.

Ofiarski Z., Ustawy o opłacie skarbowej, o podatku od czynności cywilnoprawnych. Komentarz, Warszawa 2009.

Rosenkranz A., O istocie opłaty stemplowej, referat wygłoszony na posiedzeniu sekcji ekonomicznej Towarzystwa Prawniczego, cz. I, „Gazeta Sądowa Warszawska” 1924, nr 18.

Rosenkranz A., Taryfy opłat stemplowych w układzie alfabetycznym z dołaczeniem dosłownego tekstu ustawy o optatach stemplowych z dn. 1 lipca 1926 r., Warszawa 1927.

Weinfeld I., Daniny. Podatki, opłaty, cła i akcyzy. Skarbowości polskiej tom II - wydanie piate, Warszawa 1937.

Weinfeld I., Skarbowość polska, Warszawa 1933.

\section{Akty prawne}

Dekret z dnia 3 lutego 1947 roku o opłacie skarbowej (Dz.U. poz. 107).

Rozporządzenie Ministra Skarbu z dnia 20 listopada 1926 roku wydane: co do §§ 54-64, 68-73,

78-89, 96 i 97 w porozumieniu z Ministrem Sprawiedliwości; co do $\S 102$ w porozumieniu z Ministrem Spraw Wewnętrznych; co do $\S \S 107$ i 175 w porozumieniu z Ministrem Przemysłu i Handlu; co do § 122 w porozumieniu z Ministrem Pracy i Opieki Społecznej; co do $\S \S 123,124,167$ i 168 w porozumieniu z Ministrem Komunikacji; co do §§ 99-101 oraz 103106 w porozumieniu z Ministrem Reform Rolnych; co do $\S \S 163$, 171 i 178 w porozumieniu z Ministrem Spraw Zagranicznych - a zawierające przepisy wykonawcze do ustawy z dnia 1 lipca 1926 roku o opłatach stemplowych (Dz.U. Nr 123, poz. 713).

Ustawa karna skarbowa z dnia 2 sierpnia 1926 roku (Dz.U. Nr 105, poz. 609).

Ustawa z dnia 1 lipca 1926 roku o opłatach stemplowych (Dz.U. poz. 570).

Ustawa z dnia 1 lipca 1926 roku o stosunkach służbowych nauczycieli (Dz.U. Nr 92, poz. 530).

Ustawa z dnia 2 sierpnia 1926 roku o podatku od lokali (Dz.U. Nr 94, poz. 550).

Ustawa z dnia 2 sierpnia 1926 roku o prawie właściwym dla stosunków prywatnych międzynarodowych (Dz.U. Nr 101, poz. 581).

Ustawa z dnia 2 sierpnia 1926 roku o prawie właściwym dla stosunków prywatnych wewnętrznych (Dz.U. Nr 101, poz. 580).

Ustawa z dnia 2 sierpnia 1926 roku o zwalczaniu nieuczciwej konkurencji (Dz.U. Nr 96, poz. 559).

Ustawa z dnia 1 marca 1927 roku o samoistnym podatku wyrównawczym dla gmin wiejskich byłego zaboru rosyjskiego (Dz.U. Nr 27, poz. 208). 


\section{THE UNIFICATION OF STAMP DUTIES DURING THE PERIOD OF PIŁSUDSKI'S RULE: THE LAW ON STAMP DUTIES OF 1 JULY 1926}

\section{Summary}

The law on stamp duties of 1 July 1926 is an important law of the interwar period in Poland. It was passed in the period of Piłsudski and his adherents' rule. This law constituted the act of unification of stamp duties after regaining independence by Poland. It replaced more than several dozen other legal instruments, on the basis of which different public duties, recognized as stamp duties, were charged. The law was systematic in character, it included many public duties connected with economic turnover and activity of the state authorities, as well as material and procedural regulation. This law played an important role in the development of Polish finance when it was in effect and it also influenced the historical evolution of current public duties, stamp duty and tax of civil law activities among others.

Keywords: interwar period, adherents of Piłsudski and the period of Piłsudski's rule, charge, tax, stamp duties.

Dobrosława Antonów

dobroslawa.antonow@uwr.edu.pl 